УДК 631.8:631.559

(C) 2012

Писаренко П. В., доктор сільськогосподарських наук, професор

Полтавська державна аграрна академія

Москалець В. В., кандидат сільськогосподарських наук, Москалець Т. 3., кандидат біологічних наук

Білоцерківський національний аграрний університет

Москалець В. І., стариий науковий співробітник

Носівська селекційно-дослідна станція ЧІАПВ НААНУ

\title{
АГРОЕКОЛОГІЧНІ АСПЕКТИ ЗАСТОСУВАННЯ МІКРОБНИХ ПРЕПАРАТІВ НА ПОСІВАХ ТРИТИКАЛЕ ОЗИМОГО
}

\section{Рецензент - доктор сільськогосподарських наук В. В. Лавров}

Вивчено чутливість генотипів тритикале озимого на дію мікробних препаратів альбобактерину $i$ діазобактерину. Показано, щзо на початкових етапах розвитку рослин тритикале озимого біоатенти мікробних препаратів Azospirillum brasilense ma Achromobacter album 1122 покрашують азотне й фосфорне живлення, щзо відображається у збільшенні сирої та сухої маси рослин у 1,5-2,5 рази, площі листкової поверхні - 2-2,4 рази, урожайності зерна - 1,1-1,3 рази. Відмічено, щуо конкретний генотип тритикале озимого по-різному чутливий на дію мікробних препаратів. Рослини сортів АД 256, Вівате Носівський, Славетне більш чутливі за показниками їх продуктивності у разі використання як діазобактерину, так і альбобактерину, рослини сортів ДАУ 5 та Ягуар - діазобактерину, сортів Августо - альбобактерину.

Ключові слова: тритикале озиме, мікробні препарати, продуктивність.

Постановка проблеми. У процесі еволюції грунтова біота і рослини знаходилися у безпосередньому контакті, пристосовуючись один до одного, в результаті чого сформувалися динамічно стійкі екосистеми $[3,4]$. Зростаюче антропогенне навантаження створює загрозу швидкої деформації всіх параметрів грунту і погіршення місця існування живої матерії. Для грунтів агроландшафтів це може мати негативні наслідки. Тому наразі необхідно прогнозувати реальні можливості впливу агротехнічних заходів сучасного землеробства на компоненти грунтових екосистем.

Аналіз останніх досліджень і публікацій, у яких започатковано розв'язання проблеми. Біологічна система в умовах агроценозів схильна до дії як природних, так і антропогенних чинників у вигляді різноманітних агрозаходів, які змінюють тою чи іншою мірою грунтові екосистеми. Одним iз завдань сучасного землеробства є повніше вико- ристання азотфіксуючої та фосфатмобілізуючої здатності мікроорганізмів. Нині існує чимало наукових робіт із вивчення проблем симбіотичної та асоціативної азотфіксації, фосфат- і каліємобілізації [5, 6, 8, 12, 13]. Передпосівна інокуляція насіння біопрепаратами, на основі відселектованих азотфіксуючих і фосфатмобілізуючих мікроорганізмів, сприяє підвищенню продуктивності сільськогосподарських культур на 10-30 \% $[11,14-16]$.

Тому розробка та впровадження заходів щодо формування високопродуктивних рослинномікробних систем, які б забезпечували значне зростання урожайності сільськогосподарських культур, покращання якості рослинницької продукції та збереження родючості грунтів набули особливої актуальності.

Мета досліджень - забезпечити формування продуктивного агрофітоценозу тритикале озимого шляхом застосування мікробних препаратів.

Відповідно до мети досліджень були поставлені завдання:

1. Дослідити вплив мікробних препаратів на стан посівів тритикале озимого залежно від генотипу та низки інших агрозаходів.

2. Обгрунтувати екологічну доцільність застосування мікробних препаратів на посівах тритикале озимого.

Матеріали і методи досліджень. Дослідження проводили на дослідному полі ННДЦ Білоцерківського НАУ впродовж 2008-2011 років. Ірунт дослідної ділянки - чорнозем типовий. Його агрохімічні показники наступні: $\mathrm{pH}$ (сольове) - 6,5; азот, що легко гідролізується - 140 мг/кг грунту; нітратний азот - 21 мг/кг грунту; амонійний азот 46 мг/кг грунту; $\mathrm{P}_{2} \mathrm{O}_{5}$ (за Чириковим) - 120 мг/кг грунту; $\mathrm{K}_{2} \mathrm{O}$ (за Чириковим) - 90 мг/кг грунту; гумус - 3,4\%.

Схема 1-го досліду включала 4 варіанти для 
кожного 3 шести сортів тритикале озимого (АД 256, Славетне, Вівате Носівський, ДАУ 5, Августо, Ягуар): 1 - контроль; 2 - діазобактерин; 3 альбобактерин; 4 - діазобактерин + альбобактерин;

2-го досліду - включала 8 варіантів для сорту ДАУ 5: 1 - контроль (без інокуляції та добрив); 2 - альбобактерин; $3-\mathrm{P}_{30} \mathrm{~K}_{30} ; 4-\mathrm{P}_{30} \mathrm{~K}_{30}+$ альбобактерин; $5-\mathrm{P}_{60} \mathrm{~K}_{60} ; 6-\mathrm{P}_{60} \mathrm{~K}_{60}+$ альбобактерин; $7-\mathrm{P}_{90} \mathrm{~K}_{90} ; 8-\mathrm{P}_{90} \mathrm{~K}_{90}+$ альбобактерин;

3-го досліду - 12 варіантів: 1 - контроль (без інокуляції та добрив); 2 - діазобактерин + альбобактерин; $3-\mathrm{N}_{30} \mathrm{P}_{30} \mathrm{~K}_{30} ; 4-\mathrm{N}_{30} \mathrm{P}_{30} \mathrm{~K}_{30}+$ діазобактерин + альбобактерин; $5-\mathrm{N}_{45} \mathrm{P}_{60} \mathrm{~K}_{60} ; 6-$ $\mathrm{N}_{45} \mathrm{P}_{60} \mathrm{~K}_{60}+$ діазобактерин + альбобактерин; 7 $\mathrm{N}_{60} \mathrm{P}_{60} \mathrm{~K}_{60} ; 8-\mathrm{N}_{60} \mathrm{P}_{60} \mathrm{~K}_{60}+$ діазобактерин + альбобактерин; $9-\mathrm{N}_{90} \mathrm{P}_{90} \mathrm{~K}_{90} ; 10-\mathrm{N}_{90} \mathrm{P}_{90} \mathrm{~K}_{90}+$ діазобактерин + альбобактерин; $11-\mathrm{N}_{120} \mathrm{P}_{120} \mathrm{~K}_{120} ; 12-$ $\mathrm{N}_{120} \mathrm{P}_{120} \mathrm{~K}_{120}+$ діазобактерин + альбобактерин;

4-го досліду - 14 варіантів для кожного 3 трьох сортів (АД 256, Славетне, Вівате Носівський): 1 - контроль (без інокуляції та добрив); 2 - діазобактерин + альбобактерин; $3-\mathrm{P}_{45} \mathrm{~K}_{45}$; $4-\mathrm{P}_{45} \mathrm{~K}_{45}+$ діазобактерин + альбобактерин; $5-\mathrm{N}_{20} \mathrm{P}_{45} \mathrm{~K}_{45} ; 6-\mathrm{N}_{20} \mathrm{P}_{45} \mathrm{~K}_{45}+$ діазобактерин + альбобактерин; $7-\mathrm{N}_{45} \mathrm{P}_{45} \mathrm{~K}_{45} ; 8-\mathrm{N}_{45} \mathrm{P}_{45} \mathrm{~K}_{45}+$ діазобактерин + альбобактерин; $9-\mathrm{N}_{60} \mathrm{P}_{45} \mathrm{~K}_{45}$; $10-\mathrm{N}_{60} \mathrm{P}_{45} \mathrm{~K}_{45}+$ діазобактерин + альбобактерин; $11-\mathrm{N}_{60} \mathrm{P}_{90} \mathrm{~K}_{90} ; 12-\mathrm{N}_{60} \mathrm{P}_{90} \mathrm{~K}_{90}+$ діазобактерин + альбобактерин; $13-\mathrm{N}_{90} \mathrm{P}_{90} \mathrm{~K}_{90} ; 14-\mathrm{N}_{90} \mathrm{P}_{90} \mathrm{~K}_{90}+$ діазобактерин + альбобактерин. Загальна площа варіанту досліду складала $25 \mathrm{~m}^{2}$, облікова - $20 \mathrm{~m}^{2}$, розміщення ділянок - систематичне, повторність трьохразова.

Попередник тритикале озимого - вико-вівсяна сумішка на зелений корм. У ході проведення досліду дотримувалися рекомендованої для умов Лісостепу технології вирощування тритикале озимого. Передпосівну інокуляцію насіння мік- робіологічними препаратами здійснювали в день сівби. Препарати люб'язно надані Інститутом сільськогосподарської мікробіології НААНУ. Польові та лабораторні дослідження проводили згідно з загальноприйнятими методами $[2,7,10]$, математично-статистичну обробку даних - у середовищі пакета Statistica-5.5 та Excel-2003.

Результати досліджень. Результати досліджень свідчать, що строки сівби тритикале озимого суттєво впливають на стан посівів. За оптимальних строків (20 вересня) та норми висіву зерна (5,0 млн шт./га) посіви сортів АД 256, Славетне, ДАУ 5, Вівате Носівський та інші формують дружні сходи. Чим нижча (на $3-5^{\circ} \mathrm{C}$ ) від оптимальних температура повітря в період сходів, тим глибше залягає вузол кущення, що забезпечує формування міцних пагонів першого, а потім другого порядку. У разі цього вузол кущення формує свій ярус корінців, збільшується маса кореневої системи та іï здатність забезпечувати рослину необхідним резервом для кращої адаптивності до зимово-весняного періоду. Результати аналізу з визначення сухої маси коренів рослин тритикале озимого показали, що найбільш оптимальними строками сівби $є$ початок третьої декади вересня (безсумнівно, залежно від погодно-кліматичних i грунтових умов). Посіви конкретного сорту тритикале озимого по-різному диференціювали залежно від строку сівби, що дало змогу розрізнити на більш чутливі щодо його зміщення за станом наземної та підземної частин. Найбільший приріст сухої маси коріння забезпечив сорт Вівате Носівський за ранніх і найменший - за пізніх, порівняно з сортами АД 256, ДАУ 5, Ягуар, Августо та Славетне. За оптимального строку сівби (20-25 вересня) всі залучені до дослідів сорти тритикале озимого формували потужну кореневу й наземну систему, порівняно $з$ пізніми 30 вересня та 10 жовтня (рис. 1).

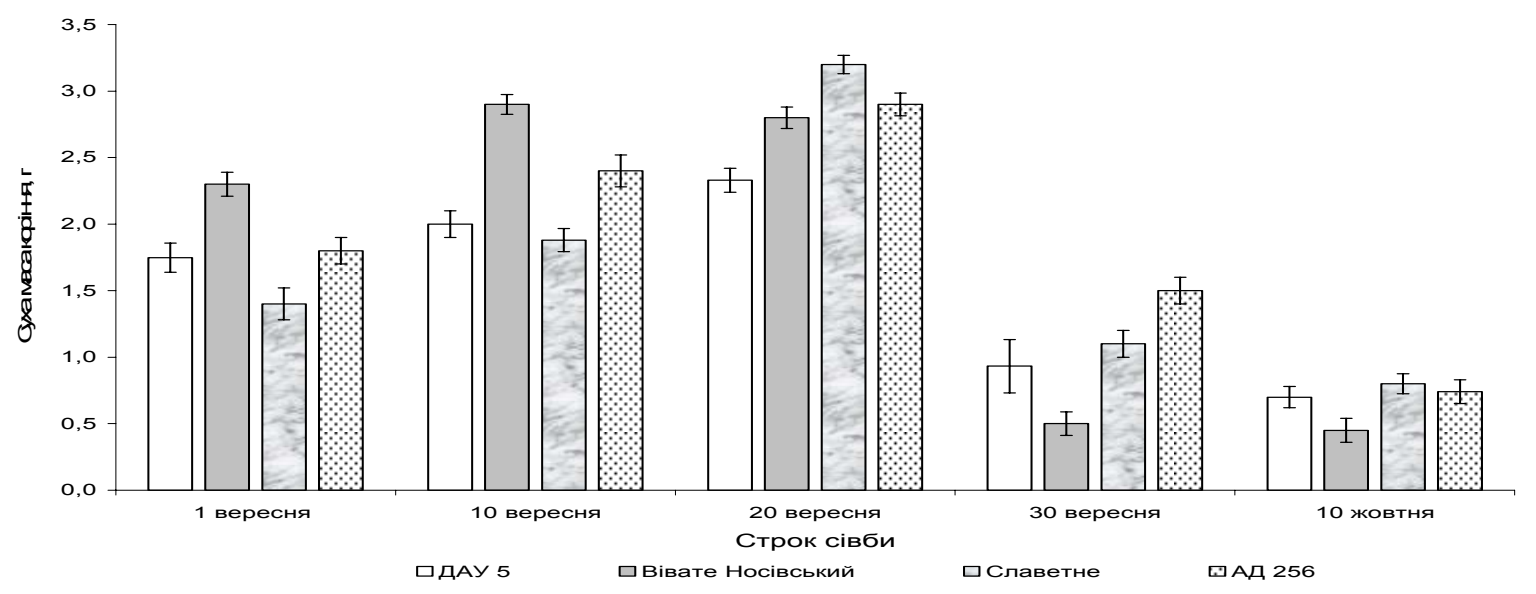

Рис. 1. Стан кореневої системи рослин тритикале озимого залежно від строків сівби та сорту (ННДЦ Білоцерківського НАУ, середнє за 2008-2010 рр.) 
Відомо, що одним з основних факторів, які впливають на інтенсивність розвитку кореневої системи, є рівень фосфорно-калійного живлення. Результати досліджень показали, що фосфорнокалійні добрива та біопрепарат фосфатмобілізуючих мікроорганізмів альбобактерин достовірно $(\mathrm{p} \geq 0,95)$ впливають на інтенсивність розвитку кореневої системи, зокрема, на нагромадження сухої речовини, порівняно 3 варіантом без застосування передпосівної інокуляції та добрив. Найвищі показники щодо нагромадження сухої маси рослин відмічено на фоні застосування фосфорно-калійних добрив у дозі $\mathrm{P}_{90} \mathrm{~K}_{90}$ спільно 3 альбобактерином. Найкраще це відмічено в посівах сорту ДАУ 5 та
Вівате Носівський, що дало змогу провести чітку межу між варіантами досліду залежно від доз фосфорно-калійних добрив, біопрепарату і строків сівби, порівняно з іншими сортами (рис. 2).

Важлива роль у покращанні стану посівів під час осінньої вегетації відведена препарату фосфатмобілізуючих бактерій - альбобактерину, який спрацював щодо нагромадження сухої речовини корінням як на фоні без мінеральних добрив, так і на фоні ї застосування. Зокрема, найкраще це було відображено на фоні мінеральних добрив у дозі $\mathrm{P}_{60-90} \mathrm{~K}_{60-90,}$, разі чого посіви сорту ДАУ 5 формували по 5-6 стебел за оптимальних строків сівби та 3-4 стебла - за пізніх.

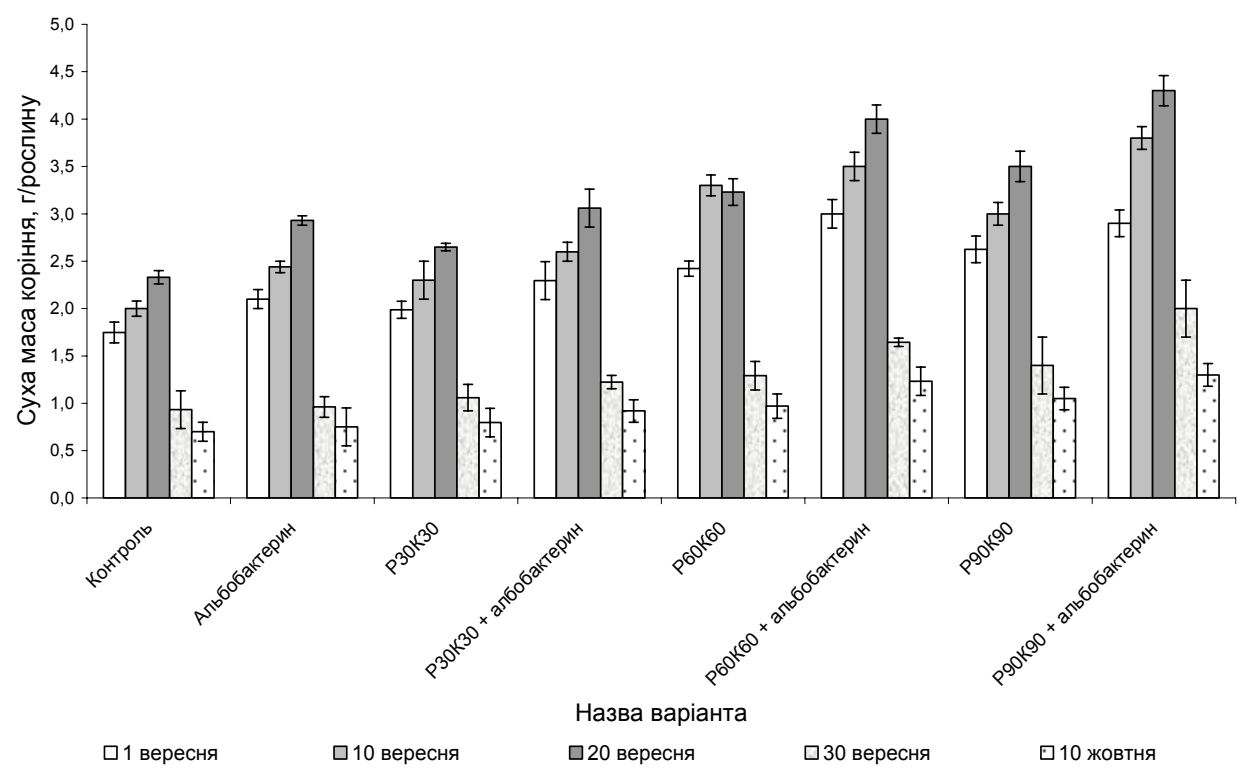

Рис. 2. Стан кореневої системи рослин тритикале озимого сорту ДАУ 5 залежно від строків сівби й застосування фосфорно-калійного удобрення та біопрепарату альбобактерину (ННДЦ Білоцерківського НАУ, середнє за 2008-2010 рр.)

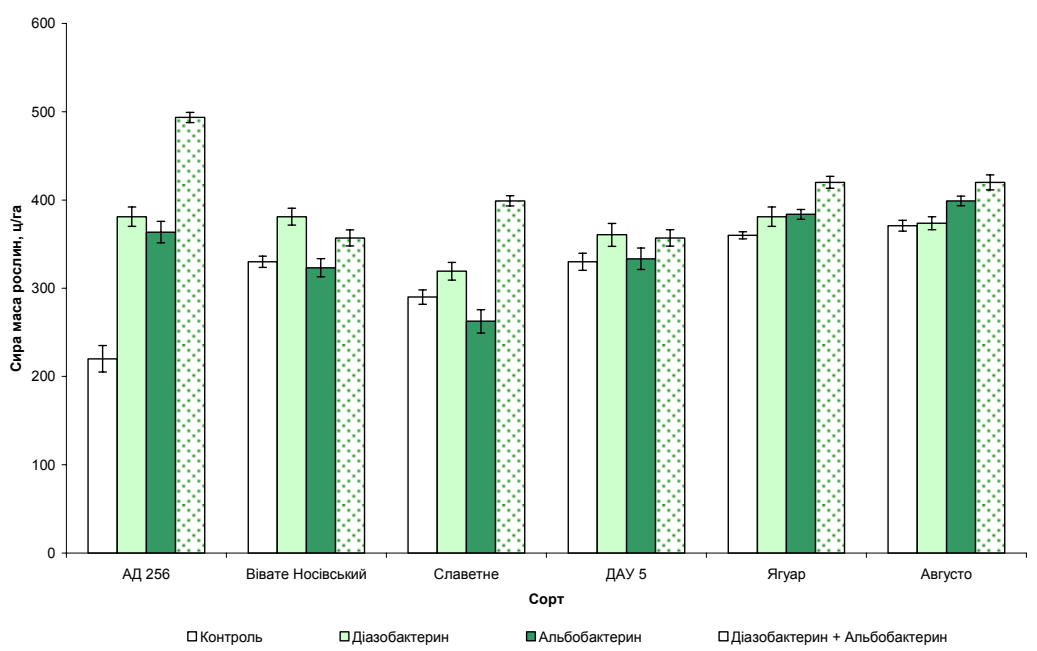

Рис. 3. Вплив мікробіологічних препаратів на показники сирої маси рослин тритикале озимого (ННДЦ Білоцерківського НАУ, середнє за 2009-2011 рр.) 
Достовірного впливу альбобактерину на збільшення біометричних параметрів наземної маси під час осіннього кущення не відмічено, порівняно з варіантами застосування мінеральних фосфорно-калійних добрив. Однак під час весняної вегетації у фазу кущення-трубкування біопрепарат фосфатмобілізуючих бактерій забезпечував формування більш вищого стеблостою 3 більшими показниками сирої та сухої маси рослин, зокрема за комплексного застосування 3 препаратом азотфіксуючих бактерій Azospirillum brasilense діазобактерину, порівняно з контролем (рис. 3-5).

Конкретний сорт тритикале озимого порізному реагував на дію мікробіологічних препаратів. Найбільш чутливими до дії комплексу діазобактерину та альбобактерину видалися сорти АД 256, Славетне, ДАУ 5, Ягуар, Вівате Но- сівський. Сорт Августо забезпечував формування продуктивних посівів, за показниками нагромадження сирої, сухої маси та збільшення висоти рослин, у разі застосування лише альбобактерину (рис. 5).

Отже, ймовірно, мікробіологічні препарати в посівах тритикале озимого забезпечують проходження на належному рівні енергетичних процесів і конструктивного метаболізму у рослин, що свідчить про наявність оптимальних концентрацій рухомого азоту та фосфору, у зв'язку з чим змінюються в бік зростання показники вегетативної маси.

Збільшення площі 1-го та 2-го листків рослин на варіантах комплексного застосування діазобактерину і альбобактерину є ще одним із доказів їх ефективності на посівах тритикале озимого (рис. 6, 7).

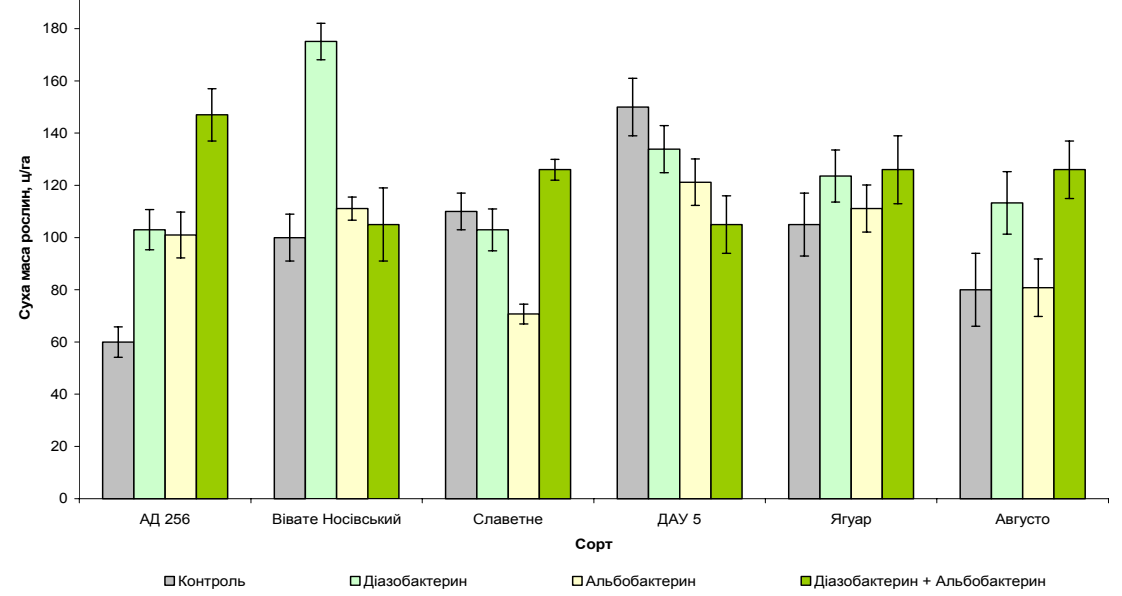

Рис. 4. Вплив мікробіологічних препаратів на показники сухої маси рослин тритикале озимого (ННДЦ Білоцерківського НАУ, 2009-2011 рр.)

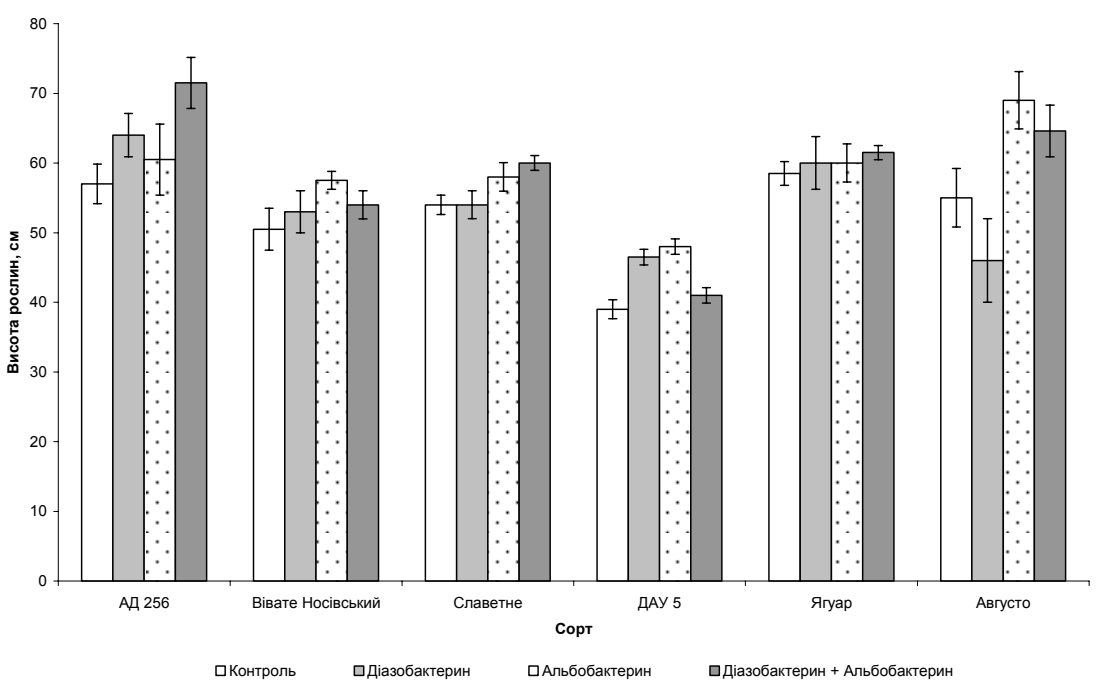

Рис. 5. Вплив мікробіологічних препаратів на показники висоти рослин тритикале озимого (ННДЦ Білоцерківського НАУ, 2008-2011 рр.) 


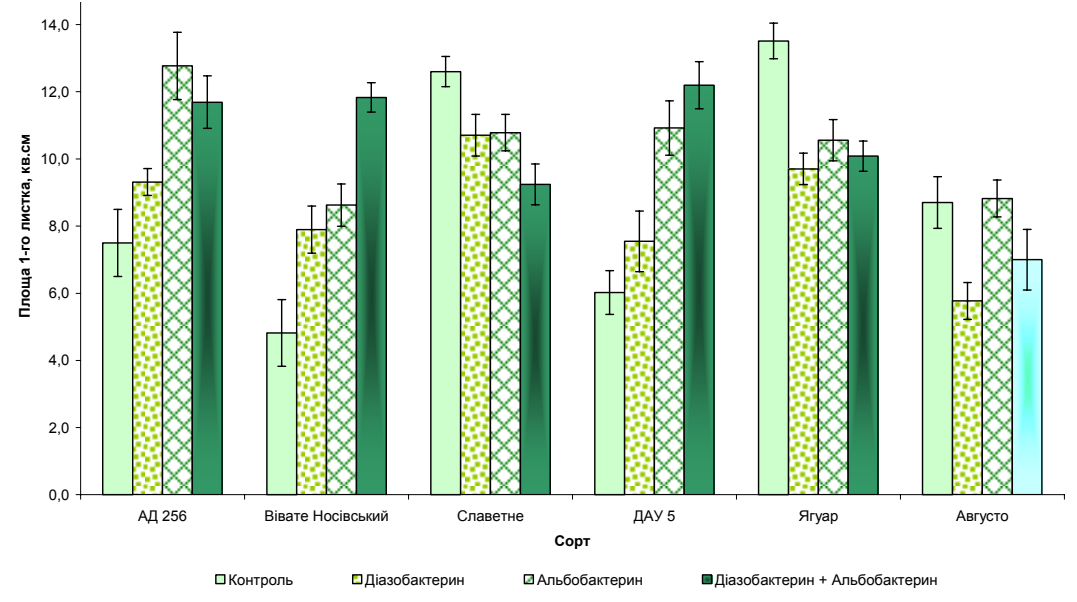

Рис. 6. Вплив мікробіологічних препаратів на показники площі першого (прапорцевого) листка рослин тритикале озимого (ННДЦ Білоцерківського НАУ, 2009-2011 рр.)

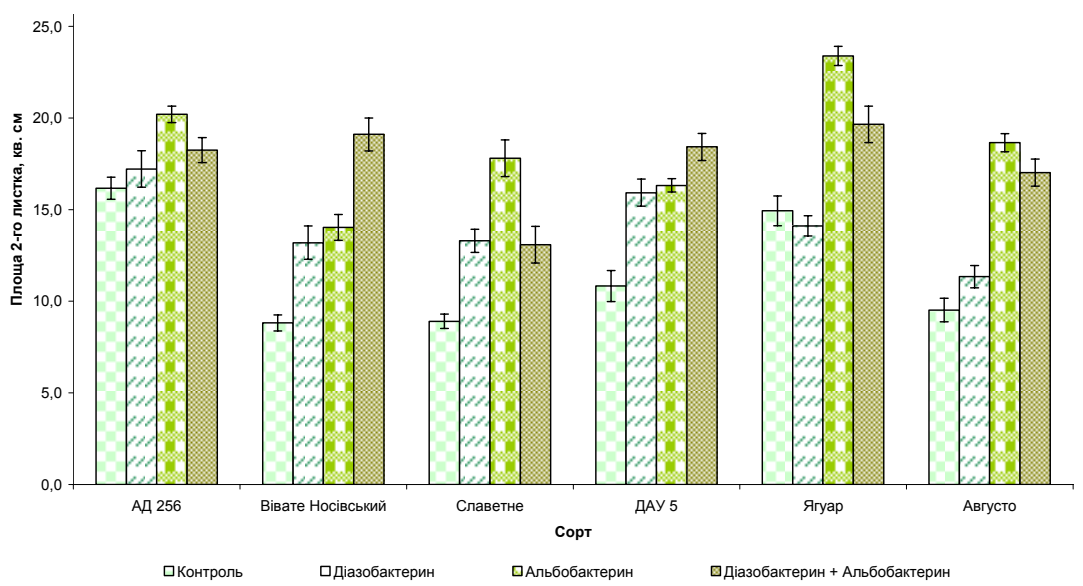

Рис. 7. Вплив мікробіологічних препаратів на показники площі другого листка рослин тритикале озимого (ННДЦ Білоцерківського НАУ, 2009-2011 рр.)

Варто зазначити, що прояв дії мікробних препаратів на стан посівів тритикале озимого відмічено на 14-у добу після відновлення вегетації навесні, порівняно з дією мінеральних добрив на варіантах їх застосування. Кількісний і якісний стан посівів тритикале озимого за показниками сирої та сухої маси того чи іншого сорту залежав від генотипу (на 38-42 \%), впливу добрив, мікробіологічних препаратів (на 25-30\%), інших агроекологічних факторів (на 37-28 \%).

Отже, мікробіологічні препарати - діазобактерину та альбобактерину - азотфіксуючих Azospirillum brasilense й фосфатмобілізуючих Achromobacter album 1122 мікроорганізмів достовірно впливають на інтенсифікацію ростових процесів у посівах тритикале, в результаті чого показники сирої та сухої маси рослин збільшується на 1,3-2,3 (за моноінокуляції) та 1,8-2,5 рази (за комплексного застосування препаратів).

Відомо, що залежно від дози азотних добрив у кореневих виділеннях концентрується певна частка азотовмісних сполук, яка визначатиме надалі активність мікроорганізмів і стан посівів у цілому [15]. Показано, що азотні добрива у дозі $\mathrm{N}_{60,90,120}$ на фоні фосфорно-калійних добрив, внесені одноразово під час весняного кущення на посівах сортів Августо, Славетне, ДАУ 5, Вівате Носівське, пригнічують активність азотфіксуючих мікроорганізмів діазобактерину, з огляду на показники стану посівів того чи іншого варіанту досліду, порівняно з їх станом на варіантах дрібного внесення мінерального азоту (під час весняного кущення, початку трубкування, колосіння). У разі цього посіви тритикале достовірно реагують на передпосівну інокуляцію діазобактерином, за біометричними показниками, лише на 20-25 добу після підживлення технічним азотом. Це, ймовірно, пов'язано зі зниженням концентрації зв'язаного азоту в системі «грунт рослина». Подібні результати відмічено в дослі- 
дження інших авторів [16]. Тому рослини тритикале озимого, маючи два джерела азотного та фосфорно-калійного живлення - біологічного й технічного походження, постійно забезпечені, 3 огляду на показники біометрії рослин.

Отже, комплексне застосування діазобактерину та альбобактерину на фоні фосфорно-калійних добрив у дозі $\mathrm{P}_{60-90} \mathrm{~K}_{60-90}$ й дрібного внесення азотних добрив у дозі $\mathrm{N}_{60-90}$ забезпечує збільшення показників вегетативної маси - висоти рослин, площі листків, сирої та сухої маси рослин.

Інтегральним показником ефективності застосування біологічних препаратів $\epsilon$ врожайність зерна. Встановлено, що сорти тритикале озимого формують різні показники індивідуальної продуктивності, які, в свою чергу, визначали такі елементи структури врожаю: маса зерна 3 головного колоса та маса 1000 зерен, які достовірно $(\mathrm{p} \geq 0,05)$ збільшувалися на 0,39-0,57 г та 2,6-3,1 г, порівняно з контролем (без застосування добрив та інокуляції), на 0,21-0,28 г та 1,3-1,5 г, порівняно $з$ варіантом застосування мінеральних добрив у дозі $\mathrm{N}_{60}$ та 90 (дрібне внесення) $\mathrm{P}_{90} \mathrm{~K}_{90}$. Слід зауважити, що оптимум дози мінерального азоту залежав від сорту тритикале, фази його розвитку, строків сівби, кліматичних умов тощо. Показано, що врожайність зерна тритикале озимого сортів напівкарликового типу ДАУ 5 та Вівате Носівський зростала майже пропорційно внесеним дозам азотних добрив на фоні фосфорно-калійного забезпечення у дозі $\mathrm{P}_{60-90} \mathrm{~K}_{60-90}$, що пов'язано 3 їх морфо-генотиповими особливостями будови - міцним і потовщеним стеблом, зокрема під колосом, що забезпечувало стійкість посівів до вилягання, порівняно 3 іншими сортами: АД 256, Славетне, Ягуар, Августо (рис. 8, 9).

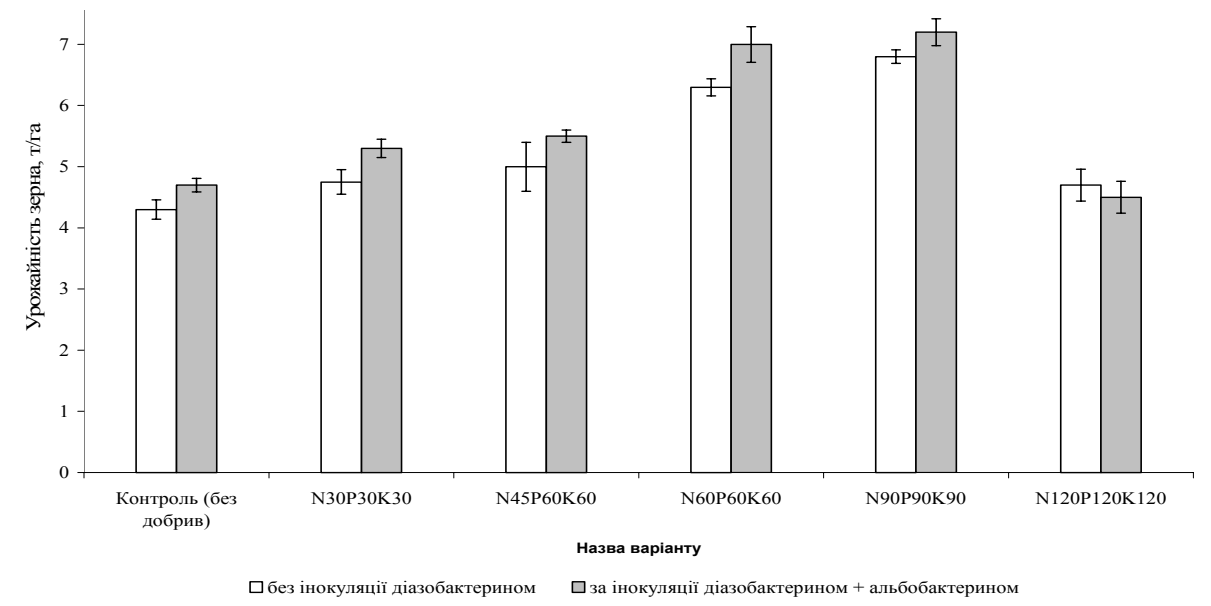

Рис. 8. Урожайність зерна тритикале озимого сорту ДАУ 5 залежно від застосування мінеральних добрив та мікробіологічних препаратів (ННДЦ Білоцерківського НАУ, середнє за 2008-2010 рр.)

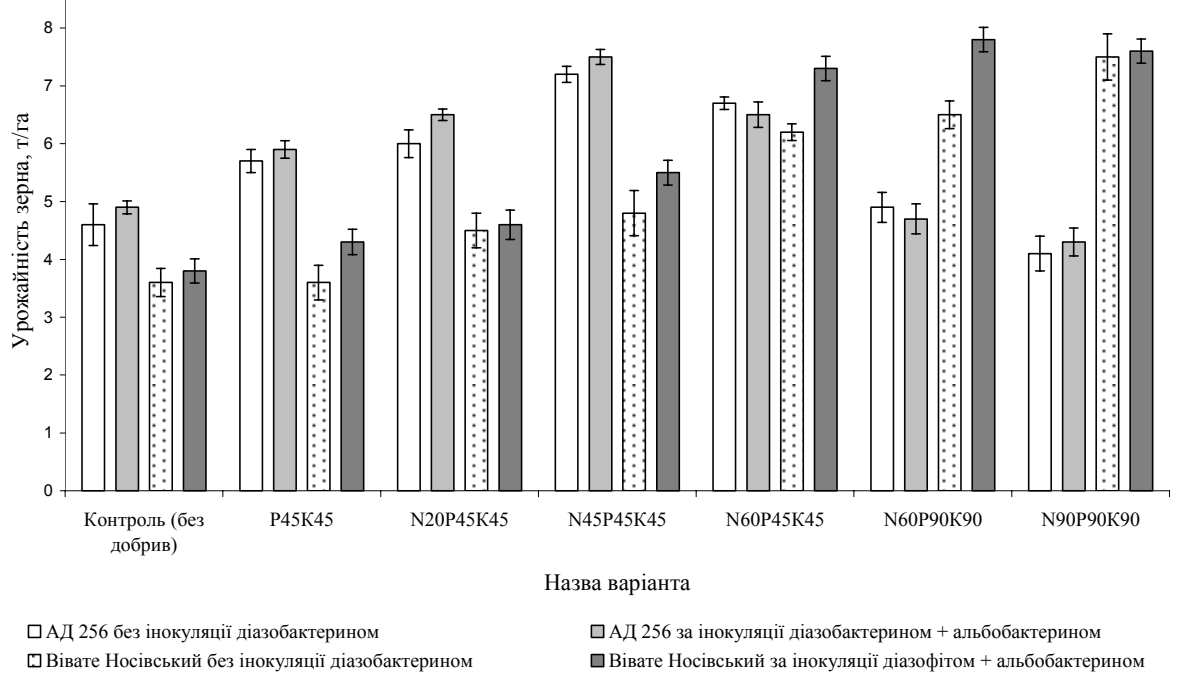

Рис. 9. Урожайність зерна тритикале озимого сорту Вівате Носівський залежно від застосування мінеральних добрив та мікробіологічних препаратів (ННДЦ Білоцерківського НАУ, середнє за 2008-2010 рр.) 
Достовірний $(\mathrm{p} \geq 0,05)$ вплив мікробіологічних препаратів діазобактерину та альбобактерину на показники урожайності зерна відмічено за комплексного їх використання на фоні мінерального живлення у дозі $\mathrm{N}_{20-60}$ (дрібне застосування) $\mathrm{P}_{45} \mathrm{~K}_{45}$ - для сортів Славетне, АД 256, Ягуар, Августо та $\mathrm{N}_{60-90} \mathrm{P}_{60-90} \mathrm{~K}_{60-90}$ - для сортів Вівате Носівський та ДАУ 5 (рис. 9, 10). Технологічна якість зерна тритикале озимого оцінюється за вмістом білку, клейковини, крохмалю та інших параметрів. Сорт тритикале озимого Вівате Носівський характеризується підвищеним вмістом білку (15-16\%), показники якого були на 1,7-2,5 \% вищими, порівняно $з$ показниками інших сортів. Зокрема вміст білку у зерні визначали як дози мінеральних добрив, у разі чого показники вмісту цього компонента зростали на 1,7$2,5 \%$, так і комплексна дія діазобактерину та альбобактерину $-0,8-1,2 \%$ відповідно.

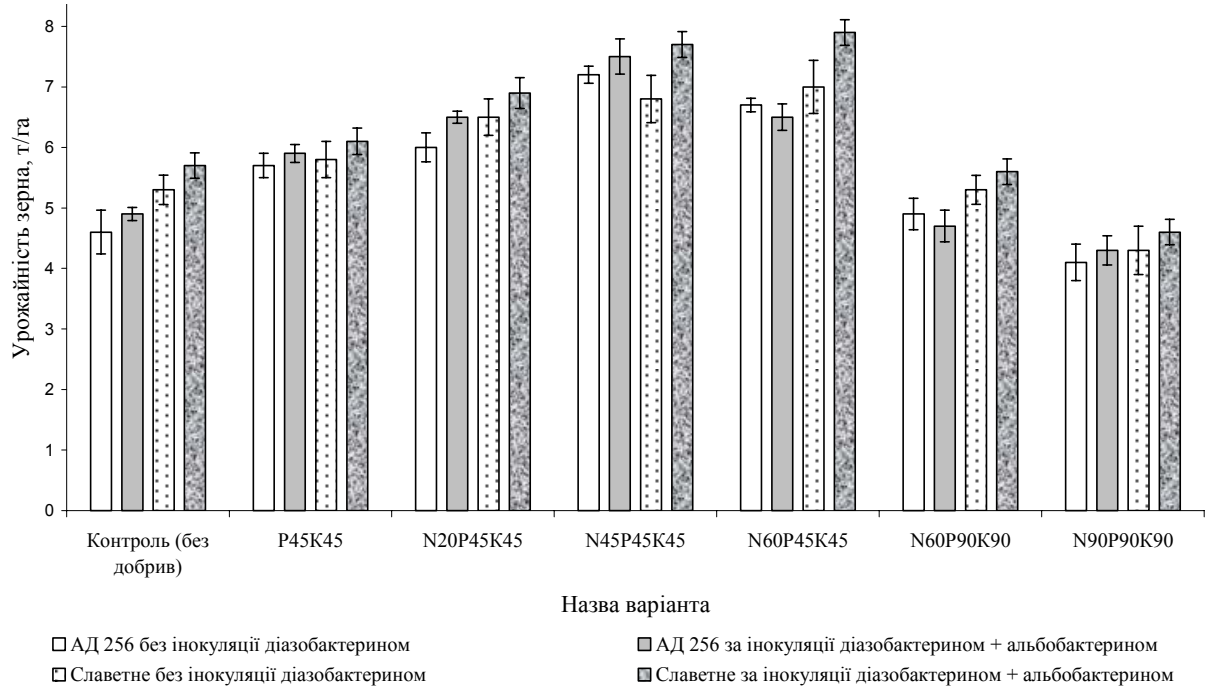

Рис. 10. Урожайність зерна тритикале озимого сорту Славетне залежно від застосування мінеральних добрив та мікробіологічних препаратів (ННДЦ Білоцерківського НАУ, середнє за 2008-2010 рр.)

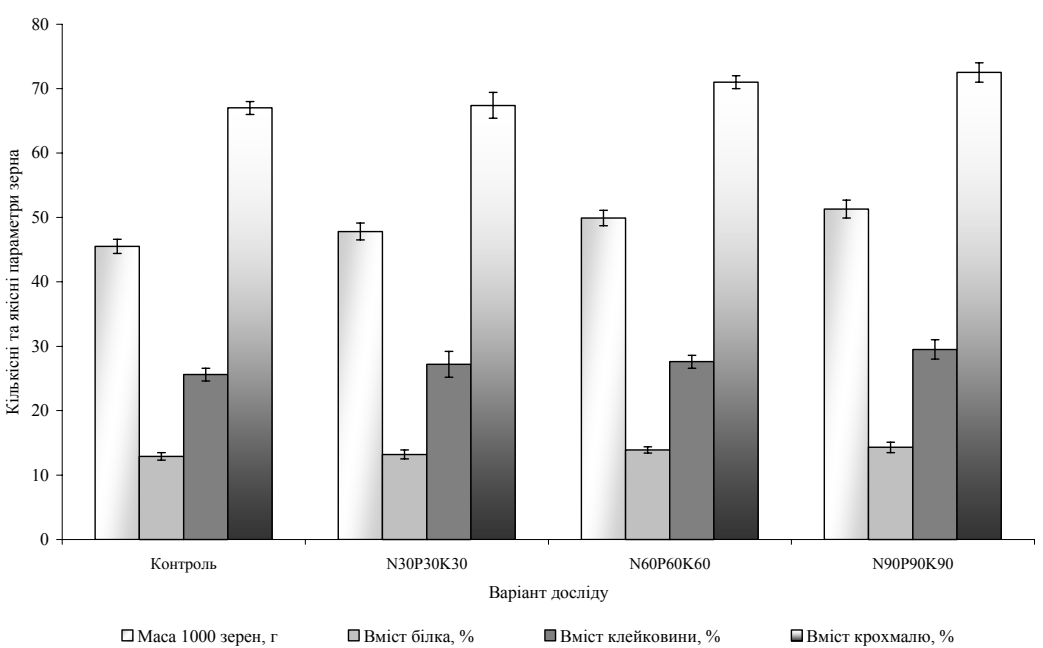

Рис. 11. Кількісні та якісні параметри урожаю зерна тритикале озимого сорту Славетне залежно від застосування мінеральних добрив

(ННДЦ Білоцерківського НАУ, середнє за 2008-2010 рр.) 


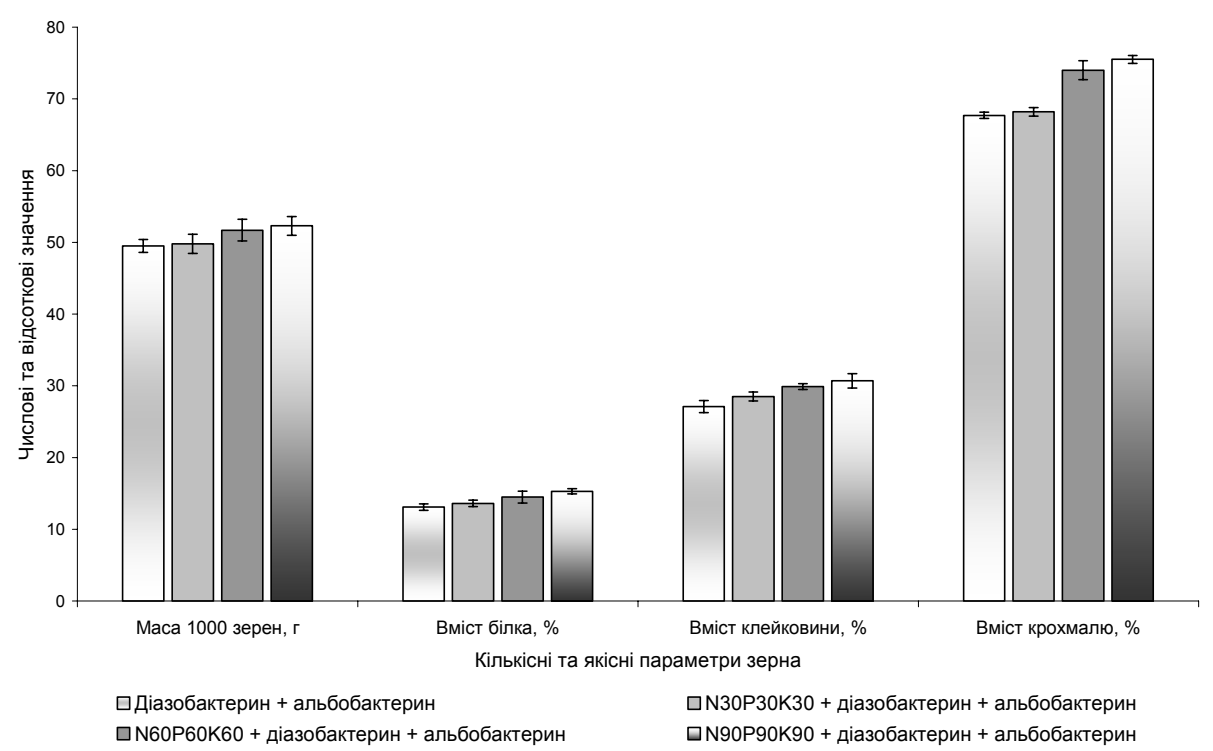

Рис. 12. Кількісні та якісні параметри урожаю зерна тритикале озимого сорту Славетне залежно від застосування мінеральних добрив та мікробіологічних препаратів (ННДЦ Білоцерківського НАУ, середнє за 2008-2010 рр.)

Максимальний вміст білку $(16,0)$ отримано за проведення дрібного азотного підживлення $\left(\mathrm{N}_{30+30+30}\right)$ у фази кущення, трубкування та колосіння. Комплексне застосування діазобактерину та альбобактерину підвищує вміст «сирої» клейковини на $0,9-1,1 \%$, порівняно 3 контролем (без інокуляції) та 2,1 \% - фоном мінеральних добрив у дозі $\mathrm{N}_{60-90} \mathrm{P}_{60-90} \mathrm{~K}_{60-90}$. Пропорційно до зміни вмісту білку та клейковини зростає вміст крохмалю, зокрема зміщення показників якого (в бік зростання) забезпечують сорти ДАУ 5, АД 256 та Славетне (рис. 11, 12).

На підставі проведених наукових досліджень і отриманих результатів у статті наведено агротехнічне обгрунтування та перспективні шляхи вирішення завдань із поліпшення стану грунтових екосистем і підвищення продуктивності тритикале озимого на основі комплексного впровадження нових сортів інтенсивного типу, мінеральних добрив та передпосівної інокуляції насіння мікробіологічними препаратами, біоагентами яких є високоефективні азотфіксуючі Azospirillum brasilense й фосфатмобілізуючі Achromobacter album 1122 мікроорганізми.

\section{Висновки:}

1. Передпосівна інокуляція насіння фосфатмобілізуючими мікроорганізмами Achromobacter

\section{БІБЛІОГРАФІЯ}

1. Волкогон В. В. Влияние минерального азота на активность ассоциативной азотфиксации / В. В. Волкогон // Почвоведение. - 1997. - № 12. - C. 1486-1490. album 1122 біопрепарату альбобактерину на фоні застосування фосфорно-калійних добрив у дозі $\mathrm{P}_{90} \mathrm{~K}_{90}$ достовірно $(\mathrm{p} \geq 0,95)$ впливають на інтенсивність розвитку кореневої системи, а саме на нагромадження сухої речовини, порівняно 3 варіантом без застосування передпосівної інокуляції та добрив.

2. Комплексне застосування діазобактерину та альбобактерину на посівах тритикале озимого зумовлює підвищення кількості продуктивних стебел (на $20 \%$ ), що забезпечує отримання оптимальної густоти стеблостою на період збирання, достовірно впливає на інтенсифікацію синтезу органічної речовини, на збільшення площі листкової поверхні.

3. Достовірний $(\mathrm{p} \geq 0,05)$ вплив мікробіологічних препаратів діазобактерину та альбобактерину на показники урожайності зерна відмічено за комплексного їх використання на фоні мінерального живлення у дозі $\mathrm{N}_{20-60}$ (дрібне застосування) $\mathrm{P}_{45} \mathrm{~K}_{45}$ - для сортів Славетне, АД 256, Ягуар, Августо й $\mathrm{N}_{60-90} \mathrm{P}_{60-90} \mathrm{~K}_{60-90}$ - для сортів Вівате Носівський та ДАУ 5. Пропорційно до збільшення кількісних параметрів урожаю зерна, зростають і якісні - вміст білку, клейковини та крохмалю.

2. Доспехов Б. А. Методика полевого опыта (с основами статистической обработки результатов исследований) / Б. А. Доспехов. - М.: Агропромиздат, 1985. - $351 \mathrm{c.}$ 
3. Звягиниев Д. Г. Биология почв / Д. Г. Звягинцев, И. П. Бабьева, Г. М. Зенова. - Изд. 3-е, испр. и доп. - М. : Издательство Московского университета, 2005. -448 с.

4. Звягинцев Д. Г. Почва и микроорганизмы / Д. Г. Звягинцев. - М., 1987. -256 с.

5. Илялетдинов А. Н. Биологическая мобилизация минеральных соединений / А. Н. Илялетдинов. - Алма-Ата : Наука, 1966. - 332 с.

6. Кретович В. Л. Биохимия усвоения азота воздуха растениями / В. Л. Кретович; за ред. В. Р. Шатилова. - М. : Наука, 1994. - 169 с.

7. Лавриненко Ю. А., Жужа А. Д., Орлюк А. П. Ускоренный способ определения площади поверхности листа / Ю.А.Лавриненко, А. Д. Жужа, А. П. Орлюк // Селекция и семеноводство. - № 10. - 1981. - C. 12-13.

8. Лукин С. А. Азоспириллы и ассоциативная азотфиксация у небобовых культур в практике сельского хозяйства / С. А. Лукин, П. А. Кожевин, Д. Г. Звягинцев // Сельскохозяйственная биология. - 1987. - № 1. - С. 51-58.

9. Мергель A. A. Роль корневых выделений в трансформации азота и углерода в почве / А. А. Мергель, А. В. Тимченко, В. Н. Кудеяров // Почвоведение. - 1996. - № 10. - С. 1234-1239.

10. Методика государственного сортоиспытания сельскохозяйственных культур. - М. : Колос, 1971. - Вып. 2. - 239 с.
11. Мишустин Е. Н. Микробиология / Е. Н. Мишустин, В. Т. Емцев. - 3-е изд., перераб. и доп. М. : Агропромиздат, 1987. -368 с.

12. Мікробні препарати у землеробстві. Теорія i практика: монографія. / В. В. Волкогон, О. В. Надкернична, Т. М. Ковалевська [та ін.]. - К. : Аграр. наука, 2006. - $312 \mathrm{c}$.

13. Патика В. П. Біологічний азот: монографія / В. П. Патика, С. Я. Коць, В. В. Волкогон; за ред. В. П. Патики. - К. : Світ, 2003. - 424 с.

14. Патыка В. Ф. Основные направления оптимизации симбиотической азотфиксации в современном земледелии Украины / В.Ф. Патыка, Н. 3. Толкачев, О. Ю. Бутвина // Физиология и биохимия культурных растений. -2005 . - № 5. C. 384-393.

15. Сільськогосподарська мікробіологія - на допомогу аграрному виробництву: Зб. наук. пр. / В. П. Патика, Г. М. Панченко, М. М. Зарицький [та ін.]. - Чернігів, 2001. -59 с.

16. Шерстобоєва О. В. Індукована асоціативна азотфіксація як елемент екологічного землеробства / О.В.Шерстобоєва, М.К. Шерстобоєв, В. В. Гармашов // Онтогенез рослин, біологічна фіксація молекулярного азоту та азотний метаболізм: матеріали Міжн. наук. конф., 1-4 жовт. 2001 р.: тези доповіді. - Тернопіль, 2001. C. 203-207. 